III-4

RSD:WBS
U. S. DEPARTIUENT OE COMIVERCE

NATIONAL BUREAU OF STANDARDS

IIay 20,1941
Letter

Circular

LC- 649

DOLESTIC HEATING AND AIR CONDITIONING

Introduction

Anyone contemplating the construction of a dwelling house should consider how to heat it, how to insulate it, and what to do, if anything, to make it cooler in summer. Insulation is mentioned here on account of its direct connection with winter heating and summer air conditioning. The better the insulation, the simpler and smaller the heating or the cooling apparatus can be.

At one time, bullding a house was regarded as one problem and heating it as another, but at present the relation between heating, air conditioring and structure, including insulation, is receiving more consideration. The house deslgner should consider the heating prohiem just as the heating engineer must consider the form and structure of the house. This is not to say, however, that these problems are in any case capable of simple or exact solution. Present day knowledge of some phases of the matter is general only and many decisions must be based on the experience or judgment of the builser, heating contractor or owner. If an owner has a predilecition for a particular kind of structure and heating system, be the latteri steam, hot water or warm air, there is no reason why he should not follow it because the probability is good that the combination can be made to perform successfully since this largely depends on proper installation and operation of equipment of proper size.

The National Bureau of Standards does not attempt to gather either statistical or experimental data on the various nakes of heating or air conditioning equipment on the market for the purpose of comparing their rejative merits. A considerable number of manufacturers are in the business of producing such equipment and changes in design or model are so common that comparative data would probably be obsolete before they could be put to use. In addition to this, the performance of such apparatus is so dependent upon its proper installation, operation and maintenance that make and type are probably no more important than the care and skill used by the installers and operators. 
Insulation

Information and reierences on the insulation of buildings are conta1ned in National Bureau of Standards Letter Circulars Nos. 465 (Aluminum Foli Insulation) and 471 (Insulation) and in Circular of the Bureau of Standards C376 (Thernal Insulation of Buildings). The Letter Circulars can be obtained from the National Bureau of Standards on request. Circular 0376 is avallable from the Superintendent of Documents, Government Printing Office, Washington, D. C., at five cents per copy.

The question of how much insulation to put into houses, or, more specifically, how much money to invest in insulation oiten arises. Some authorities consider it worth while to estimate the useful life of a house as well as possible and to proportion insulation cost and probabie savirg in heating cost so that the insulation will pay for itself within a given time.

Anvther approach, proposeā by R. K. Thulman in a paper entitled "A Proposed Basis for Establishing Hinimum Requirements for Insulation" presented before the National lineral Wool Association in Iry 1940, is to consider confort rather than cost as the determinirg factor. Since a house with warm walla has a more uniform ternereture distribution than one with cold walls, it is proposed to instaji sufficient insulation so that the inside wall surface tempersture will not be below some given temperature ( $65^{\circ} \mathrm{F}$ was suggested) when the house is heated to $70^{\circ} \mathrm{F}$ on a day when the outdoor temperature is as cold as the heating system is designed for.

Either of these methods leads to the use of less insulation for a warm climate than for a cold one. Neither considers the amount of insulation which should be installea in warm localities to keep the heat out. AII we can say in this respect is that insulation in the ceiling or roof structure will aid materially in keeping the house cool in hot weather.

In and around Washington, D. C. mony houses are insulated in the ceiling with erom two to trree inches of fill material, poured or placed between the joists. Side walls are often insulated with material available on the market in the form of blankets or batts, about two inches thick, covered with treated moisture-and-vaporproof paper. Such material is sometimes installed in the roof structure when it is desired to warm the attic and when this is done, a space ventilated with outdoor air is essential between the insulating material and the roof boards, for reasons which are discussed in the next section, on vapor barriers. 


\section{Vapor Barrieis}

Water vapor barriers are now considered essential to insulat ed walls. Since houses are generally kept closed in winter for warmth, cooking and washing operations, which liberate water vapor, or the use of liumidifiers make the anount of water vapor per cubic foot of air much greater on the inside of the house than it is out of doors.

This water vapor has a tendency to "migrate" through porous or hygroscopic walls from the insice toward the outside of a house and if it reaches a portion of the wall where the temperature is below the dew point, condensation of water vapor into water or ice occurs which can damage the insulation and sometimes cause rot in timbers.

Condensation does not occur in all walls, and, if moisture can escape from the wall to the air outside the house more readily than it can enter the wall irom inside the house, there will be no accumulation of moisture within the wall even though condensation should occur at tines. Installation of a lnoisture barrier"l near the inside surface of the walls, however, is often worth while as a precaution. The barrier should certainly be on the warm side of (that is, toward the house frorn) the insulation to retard the passage of weter vapor toward the colder portions of the wall near the outside. Any barrier on the outside of the insulation is detrimental so far as condensation is concerned. Frotection against rain is necessary, of course, but is a separate problem from that under consideration here.

Several products, such as some of the tarred papers, either designed or suitable for the purpose, are available on the market. Such materials are usually applied as barriers behind the laths and plaster or wajl board, tilet is, between the plaster and studs. ordinary building peper only is not considered sufficiently vapor resistant to serve as a vapor barrier.

Houses sheathed wth metal or other vapor proof material on the outside require special consideration, usually involving ventilation of a space between insulation and sheathing to the outside.

Heating

No comprehensive ard reijable test data are now available as far as we know by means of which a conclusive comparison of the 
steam, hot water and warm air (including the winter air conditioning) heating systers can be made. Each has its proponents and the cholce between the three is often based on personal preference. There is no reason why an efficiency or an economy obtainable with one of the three cannot be obtained with another. In practice, efficiencies uridoubtedly differ considerably on account of the difference in the care and skill with which heating plants are installed and operated and no statistical study has been attempted to determine which of the three systems affords the greatest efficiency in the average case. The probability is that there are warm air systens with better efficiencies than some hot water systems or steam systems and some hot water or steam systems with better efficiencies than some warm air or winter air conditioning systems, etc. The conclusion is that the type of system is not the determining factor where efficiency is concerned and cannot be used as a basis for the comparison of efficiencies.

The United States Housing huthority has suggested some efficiencies for use in estimating fuel consumption. In practice, actual efficiencies may differ considerably from those suggested, as explained above, but the suggested efficiencies, with some assumed fuel prices and approximate fuel heating values, have been applied in computations and the results are tabulated below as a means of comparison. If actual prices and known efficiencies differ from those assumed, the tabulated costs of heat can readily be corrected by direct proportion in the case of fuel price and by inverse proportion in the case of efficiency.

Heat Cost Cerits per Ivilition

Fuel.

\section{anufac- Conversion}

tured gas.. burner 600 Btu/Cu Ft anufac-

tured gas.. Gas boiler atural Conversion

gas....... burner

atural

gas........Gas boiler

iI (iI) ... Jot or sleeve burner

ituminous Hand or coal........stoker nthracite hand or coal.......stoker
II II 11

1000 " 11 " $"$ " " "
$136000 \mathrm{B \tau U} / \mathrm{gaI}$ $14000 \mathrm{Btu} / \mathrm{ID}$ $12000 \mathrm{Btu} / \mathrm{Ib}$
Fuel Cost Btu

The efficiency estimate used in the following comes from another source:

\section{il (\#2) .... Iuechani-}

139000 Btu/gal.

$7 \not / \operatorname{gal}$

$65 \%$ 
The above figumes are considerea to apply to central donestic heacing plants. Authoritative estinates of fireplace, fireplace grate, coal stove or wood stove efficiencies are not available. Our best information inaicates that fireplace efficiency probably lies in the range from 10 to 25 percent. stove efficiencies may be very good, that is above 50 or 60 percent. An unvented device such as a gas burning radiant heater must heve a very hish heating efficiency, above 90 or 95 percent, depending on the efficiency of combustion, since no heat is lost in the flue gras. A disadvantage here is, of course, that the occupants of the room must breathe and be surrounded by air contaminated by the products of combustion.

The efficiencies in the above table are intended to represent typical performance and not the best possible. The eficiencies practically attainable with coal can probably be improved 15 or 20 percent over those shown by careful firing and economical use of fuel and hest.

The heat value of wood depends greatly on its dryness. Data on air-dry wood contained In Kent's ivechanical Engineers' Handbook indicates that, in heding value, one cord of winte pine is approximately equal to half a short ton of coal; a cord of yellow pine, to three-quarters of $s$ ton, and a cord of white oak, to seven-eigitis of a ton, ete.

First cost is a factor in choosing a heating system and, althoug some general statements on the subject can be made, the only means of aeciding with any aegree of exactness which system will be least costly to install in a proposed house is to compare cost estimates for the various types. Such estinates can be obtainea from conpeting contractors in a position to survey the proposed job and guarantee performance.

The warm air heating system is nore aphlicable to the "compact" than to the "rambling" type of house on account of the comparatively large size of the aucts. On the other hand, when heat is conveyed several hundred feet, as fron a boller house to a building, a steam line is usual because more heat can be economically conveyed. through a pipe of a given size by neans of stear than any other commonjy used medium. gtean hering pipes in a nouse can be smalew than hot weter heating pipes but the steam system may require control and safety devices, so that the hot water system may be the cheaper to install. Apparently the size range of dwelling houses is such that steam, hot water and hot air, can and do compete with each other as meala for conveying heat through the distances involved in heating systems for such houses. 
The above is written as if the case were clear cut and only a simple consideration of stean, hot vater and warm air systems were necessary. In reality varieties of each of the three systems are in common use and a comparison in detail of all of them would be too lone fr presentation in a letter circular.

It is probable that the simplest type of warm air system is, on the average, cheapen to install than the simplest steam system and the simplest steam system cheaper to install than the simplest hot water system, but the control equipment essential to satisfactory heating in houses of various designs oten alters this relation between first costs. In goneral, it 1 s. desirable that the heating equipment be designed or selected to suit the house.

Humidification

Humidification is very convenienty accomplished with warm air heating systems. Several types of humidifiers, including spray types and pan types, some completely automatic and some requiring manual filling and control, are available ior use with such heating systems. Pans desinned to hang on radiators are the only humidilying aevices known to us which are readi nade for use with steam or hot water heatine sistems.

There is reason to believe that excessive humidity in houses is more likely to cause difficulty than insufficient humidity. The first evidence of excessive humidity is likely to be conaensation on windows which can result in streaked walls from water running from window panes, but a matter which can be more serious is condensation in tie structure of walls, with resultant deterioration of timber, insulation, etc.

Reliable data correlating humidity and health are not available and no optimum humidity has been establishea by competent medical authority. The fact is, thereiore, that winter humidefication depenas on rersonal taste. It one is convinced that he is more comrortable or healthier with, uhan without water vapor added to the air in his house, he should use a humiaifier, taking due precautions agairst amage to the house such as that described above.

This subject is treated in more detail in University of Illinois Bulletin No. 230, entitled "Humidification for Residences", published by the University of Illinois, Urbana, Illinois, and in an article by C. F. Yaglou entitled "Physical and Physiolosic Principles of Air Conaitioning" wilch appeared in the Journal of the American liedical Association for hay 15, 1937. 


\section{Computations}

Iuethods for computing heat losses from buildings, or heat gains for air conditioning, are contained in the "Guide", handbook of the American Society of Heating and Ventilating Engineers of 51 liadison Avenue, New York, $N$. $Y .$, and in various texts on heating and air conditioning.

In brief, it is now custonary to compute heat losses by multiplying a factor, U, (Btu per hour per square foot per degree temperature difference) by a temperature difference betweer inside and outside, assumed for design purposes, and by the area of the exposed wali, window or other iten under consideration. This operation is carried out for each exposed area in each room to estimate the heat loss for each room and the sum of the heat losses from the roons is taken to be the heat loss of the house. To this are added estimated heat losses due to air leakage into the house and facturs oi safety, such as adding fifteen percent to the estimated heat loss of rooms exposed to prevailing winter winds, are sometimes applied.

Hert gain computations for summer air conditioning are made similarly, the hext, flow being in the opposite direction, of course. Correcticis for sun load and for any heat liberated in the house by ligh:s, cooking and washing operations, etc., must be applied for sumer air conditioning and the dehumidifying load is normally quite important.

Values of $U$ for various builaing elements are contained in the reference mentioned above. This Bureau is now engaged in the experimental determination of $\mathrm{U}$ for some wall constructions of interest in connection with low cost housing and the results will probably be published in the near future.

The design temperature difference is usually obtained by assuming an indoor temperature of $700 \mathrm{~F}$ and an outdoor temperature 15 degrees $F$ higher than the lowest temperature recorded for the region during the preceding 10 jears. Design temperature data are contained in the ASIVE Guide and other references.

\section{Radiators and Convectors}

After computing the heat loss from a room as described above, it is necessary to find a heating device of sujtable capacity. Radiators and convectors are usually rated in Square Feet Equivalent Direct Radiation, abbreviated EDR. A surface is said to have one square foot EDF when it has the ability to transfer $240 \mathrm{Btu} / \mathrm{hour}$ 
to a room at $70^{\circ} \mathrm{F}$ with steam at $215^{\circ} \mathrm{F}$, which corresponds approximately to one pound per square inch gage. This probably came about because, in the early days of radiator testing, some type or types radiators dissipated about 240 Btu per hour for each square foot of radiator surface. There is now some agitation for the abandonment of the square foot EDR in favor of the Inbh, meaning 1000 Btu per hour.

A "square foot of hot water radiation" is conventionally defined as an amount of radiator which will dissipate 150 Btu per hour.

To estimate the size radiator or convector to install in a given room the estimated heat loss from the room is divided by 240 to obtain the square feet EDR for steam or by 150 to obtain the squire faet of hot water radiation.

Ratings of raciators and convectors are published by manufacture"s in their catalogues and when the required capacity in square feet or hot water radiation is known, one of suitable size can be chosen from a catalogue.

Radiators and convectors are now tested at the National Bureau 0I standars: as a part of the low cost housing program and, although the resur..s in detail are considered confidential, it can be said that cast ron radators and top out let convectors are fairly conseriatively rated in catalogues but that front outlet convectors shzuld, in some cases, be chosen some 20 percent oversize if they are to develop required capacity on a condensate basis.

There is no reason to suppose that the cost of heating is materially higher with convectors than with radiators or vice versa. The first cost of convectors is likely to be the higher. Adequate insulation, say an inch of typical commercial insulation, should be installed behind convectors set into exposed walls.

Boilers

Boilers, like radiators and convectors are rated in square feet EDR or in square feet of hot water radiation. It has been the practice to install heating boilers with ratings from $1-1 / 2$ to 2 times the estimated heat loss to allow for rapid warning up of the system and the losses from the piping.

Some new bolier codes have been published by the Institute of Boiler and Radiator lianufacturers of 60 East Eorty second street, New York, iN. Y. Boller ratings under these codes, to be known as 
I-B-R ratings, are in tems of actual cornected radiation. Allowances have already been made for piping loss and warming up in the ratings thernselves.

Bteel heatine bolleis are doually rated in accordance with the recomnendations of the Stecl. Heating Boiler Institute, lidaletown, Pennsylvania, and these recomendations are contained in NotionaI Bureau of Standards Simplified. Practice Fecomendation $R$ 157-37. The bases for such retings are assumptions of a ratio of 34 to 1 between radiator surface (EDR) and heating surface for hand fired boilers and of a ratio of $I 7$ to 1 between radiator surface (EDF) and hating surface for mechanically fired boilers.

Reljable data on wich to estinate the relative durability of cast iron ana steel boilers or furnaces are not avallable. Cast iron boilers and furnaces are enernlly or thicker metal than those of steel and have the reputation of being more resistant to corrosion but also of being nore subject to cracking than such devices rilade of steel. This means that for any given case, it cannot be definitely known in advance that a boiler or furnace of one material will outlast one o? the other naterial. The probability is that a steel boiler will require attention earlier than one of cast iron. The tubes in steel bollers must sornetimes be replaced on account of corrosion. Some engineers do not favor boilers with the tubes welded in because tube replacement in such boilers is aifficult.

Warm Air Heating Systems vith Natural Air Circulation

Iuch of the design data nin varm air heating systems was developed by the Engineering Experinent station of the Iniversity of Illinois, Urbana, Illinois, and the National Warn Air heating and Air Conditoning sisociation of Columbus, Onio.

In natural ciculation wam ais systems, a separate duct from the furnace to each roon is usual. This auct is composed of a "Ieader" in the basement which connects "je furnace to a vertical "riser" or "aci" which delivers warm ir to the register in the rom. Systan ane sometimes designed or tho assumpion thet leaciers wil. cilvex the following anounts of heat for exch square inch ou their crosi-sectional area:

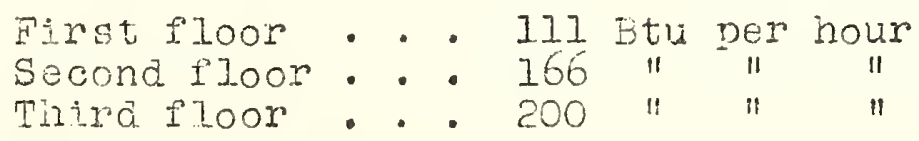


The course of the duct should be as direct as possible. Leaders over 8 feet long may require special consideration. This explains why the furnoce for this type of system is usually placed at or near the midale of the bosement. Stacks for upper floors should have at least 70 percent as much cross sectional area as their respective leaders. The cross sectional area of the return duct should equal or exceed the sum of the areas of the heating ducts.

\section{Warn Air Heating Systems with Forced Air Circulation}

Small forced circulation warm air systems with individual ducts of approximately equal length can be designed on a basis of equal air velocities in the various ducts. A cubic foot of air at $1500 \mathrm{~F}$ will deliver nearly 1.25 Btu to a room at $700 \mathrm{~F}$. On this basis a duct of one square foot cross sectional area with an air velocity of 500 feet per minute will deliver about $500 \times 1.25 \times 60=$ 37,500 Btu per hour under the same conditions. A fan or blower must be installed to furnish the necessary air motion.

The above will give the home ower an idea of the design of warm air systems. The problem is complicated when the system is large, when the ducts are of unequal length and when the heat losses from the ducts themselves must be considered. Those interested in the details can consult the "Guide", handbook of the American Society of Heating and Ventilating Engineers, "Gravity Warm A1r Heating" and "Winter Air Conditioning - Forced Warm Air Heating" by the National Warm Air Heating and Air Conditioning Association and various texts on the subject.

\section{Oil Surners}

Government publications on oil burners are Agriculture Dem partment Circular 406 "Oil Burners for Home Heating" and National Bureau of Standards Commercial Standard CS75-39 "Automatic Wlechanical araft Oil Burner's Designea for Domestic Installation". Copies of these publications are available from the superintendent of Documents, Government Printing Office, Washington, D. C., at 5 cents each.

Agriculture Department Circular No. 406 contalns some discussion of the various types of o:l burners, gun, rotary, pot, etc., but it does not contain comparisons by make or brand.

NBS Comnercial standard CS75-39 contains some specifications for oil burner construction and performance and a list of acceptors of the commercial standard. The specifications were established 
at a meeting held under the auspices of the Trade standards Division of this. Bureau at which users, dealers and manufacturers of oll burners weire represented.

A spécification contained in the Commercial standard is that the burner shall, when in ordinary service, produce at least 8 percent carbon dioxide in the flue gas without visible smolse at the chimney outlet. Some service men and FHA inspectors now equip thenselves with orsat or other suitable apparatus for inaking f'lue gas analyses.

The Netional Bureau of Standards has no data on which the various makes or types of oil bumers can be compared. Good oil burner performance is dependent upon proper bafizing in the fire box, sufficient boller heating surface and in general unon the care and skill with which the burner is installed and operated. Wake, selling price, and type of burner are therefore not the only criteria of performance. Tests ard inspections for compliance with the above Commercial standard are made ot an independent laboratory, not by this Bureau. The Commercial Standard applies to both the rotary and the eur types of burners.

\section{Stokers}

A Government publication on stokers is National Bureau of Standards Commerclal Standerd CS48-34 "Domestic Bumers for Pennsylvania Anthracite".

Some information on stokers may be obtainable from the stoker Wanufacturars Association, 307 North Iichigan Avenue, Chicago, IIIInois.

Some recommendations on anthracite stokers are contained in publications oi the Anthracite Inaustries Isboratory, Primos, Pennsylvaniz, and practical solutions of coal ana ash honding problems are avaliable from the same source.

\section{Air Conditioning}

Air conditioning can be dethed as the preparation of the air in a space for hutian confort. In this sense the problem naturally asvides itself into two parts: winter air conditioning, for which heat is added to the air and sumer air conditioning, for which heat is taken from the air.

Since the equipment now generaliy called winter air conditioning; equipment prepares the air before it enters the conditioned 
space, it is perhaps wore properly termed air conditioning equipment tian are stoves, radiators, convectors, etc., which emit heat by convection and radiation in the occupied space.

Vinter air conditioning equipment has come to signify some form of forced-circulation warm air system, usually with humidifiers, air filters and autoratic controls. The remarks above unati Heating are applicable to it.

There are a number of ways in which comfort conditions in houses can be improvea in summer. People have been accustomed to fairly heavy expense for hesting for a long time but since they have been without artificial cooling until comparatively recently there is a reluctance on the part of many to accept the expense necessary for complete air conditioning.

A complete domestic air conditioning plant would incluae a refrigerating machine and a means of using the machine to cool and dehumidify the air in the house. An obvious application is to install the macline in conjunction with a forced circulating warm air system and to use the same ducts ior heating in winter and cooling in sumer. It is probable that ducts and/or the circulating fan which are designed particularly for heating will not be entirely proper for cooling the house and the system should be designed with this in mind. The chief expense is likeli to be the first cost of the refrigerating machine and the cost of power and perhaps water necessary to its operation. As a very rough guess, this expense, to equip a sir or eight room house, would amount to rom 300 to 1000 for the equipment and the cost of sufficient power to operate a 3 to 5 horsepower notor. Water tó cool the condenser may be a consiaerable item. Some experiments with equipment of this type in the Research Residence at the Engineering Experiment Station of the University of Illinois ard described in a peper entitled "Investigation of Summer Cooling in the "farm Air Research Residence". The price is one dollar.

If a householaer is so fortunte as to have available a copious source of cool water such as a well or spring he can utilize a systern similar to the above without purchasing and without the operating expense of the refrigerating machine. To be useful the water temperature should be $600 \mathrm{~F}$ or below and the flow should be, say, from $b$ to 15 gallons per minute or more for houses, depending upon their size. Such water can be effectively used, also, in a simple unit cooler and home made unit coolers have been constructea of automobile radiators, throueh the tubes of which such water ilows or is pumped and between the fins of which air is forceâ by suitable pans or blowers. Such radiators, if used, should be installed with their fins inclined to facilitate draining 
and with drip pans or drains to dispose of water condensed from the atmosphere.

Unit air conditioners suitable for single rooms are on the market and are less expensive than equipment for a whole house. Descriptions can be obtained from the several manufacturers and such equipment is covered by Federal Specification 00-A-361, "Air-Conditioning-Units (Room Coolers); Electric-ivotor-Driven, Portable." Copies are available from the superintendent of Documents, Government Printing Office, Washington, D. C., at 5 cents each.

A convenient air cooling device useful in dry climates is the direct evaporative or desert-type cooler. It consists essentially of a mass of excelsion, say a couple of feet square, kept wet by a water drip and backed by an electric fan to force the air through the wet excelsior and into the house or occupied space.

Some information on the subject has been obtained from the Southern Sierra Fower Company, Riverside, Califomia.

The cooling action results from the evaporation of the water from the excelsior, possible in regions op low humidity. The probab1lity is tret the device would be practically useless in a region of the United States east of the IHIssissippi.

A widely practicable means of improving comfort conditions in summer is the use of an attic ventilatine fan, an extension of the very old practice of ventilating for cooling by simply opening windows. The equipment usually consists of a fan, from $1-1 / 2$ to 4 or 5 feet in afameter depenaing on the size of the house, installed in a window, door or other opening in the attic to exhaust the air out of the house. Open doors, and sometimes grills installed for the purpose, permit passage of air from other parts or the house to the attic. A usual practice is to start the fan during the early hours of the evening and so take advantage of the temperature arop which usually accompanies night fall. With the fan operated only at night and the house closed during the day, the house may be kept cooler than the average temperature out of doors. Nanufacturers of fans designed for this purpose recomend sufficient fan capacity for one air change in the house in from 2 to 5 minutes. This will result in a breeze through any open window or door. Lesser capacities would also be of some benefit. A small ventilating fan in the kitchen to expel heat and vapor incident to cooking often materially improves comfort conditions in the whole house.

It is important to make all openings through which the air must pass ample in size. Considerable volumes of air can be moved at low speed witr little power. 
